\title{
The Use of the Common Assessment Framework Tool: Empiric Study on the University of Évora (Academic Services)
}

\author{
T. Nogueiro and M. Saraiva \\ Universidade de Évora \\ Évora/Portugal
}

\section{Introduction}

Quality of life is an important social issue. Nowadays, consumers are well aware of the close relationship between quality, environment, hygiene and safety at work and social responsibility. They ask for an ethical and responsible management, the prices they have to pay for services or products being the least of their concern (Lopes and Capricho, 2007).

The new concept of Quality integrates the new social paradigm of advanced societies. The evolution of this concept reveals the cultural evolution of a country and of a people, although in practical terms beliefs, values and principles tend to juxtapose.

The theme Quality has also called the attention of several authors, such as Juran (1964), Crosby (1979), Deming (1986), Moller (1992), Feigenbaum (1949), Ishikawa (1985) and Taguchi (1986) and came up in the United States of America during World War II. By that time it was essential for the success of the army industry to control the quality of the weapons produced and sold (Shingo, 1986; Moller, 1992). This idea was exported to Japan where it acquired another dimension, allowing the reconstruction of the post-war Japanese industry ( Pires, 2004; Evans and Lindsay, 2005).

To implement a process of change within an organization is not normally an easy task. Today, among the competitive advantages of any organization, the quality of the services it delivers is a major goal (Araújo, 2001 and 2004). To determine the quality of any service one must assess/measure that advantage, and public sector organizations should not be an exception; they must have that extra responsibility. Such organizations should not only provide what clients need, but they should also serve their needs (Kaboolian, 1999; Silva, 2000; Rocha, 2006). Consequently, one of the competitive advantages of the organisations is the quality of the services they provide (Skelcher, 1992; Sharitzer and Korunda, 2000; António and Teixeira, 2007). It is necessary to know the quality of a service, public organisations included, to evaluate and to measure it in order to enhance quality (Swiss, 1992; Rago, 1994; Morgan and Murgatroyd, 1994; Gonçalves and Monteiro, 1999; Loffler, 2001).

The evaluation of public organisations has been a reality all over Europe. In 1988, the responsible for the Public Administrations of the several State Members of the European 
Union launched a project of Quality Management, aiming at the creation of the Common Assessment Framework (CAF) (Dearing, Staes and Prorok, 2006; INA, 2006).

The Common Assessment Framework (CAF) is a self-assessment easy-to-use tool to apply in any public service organization, with well-defined and useful practical results (Saraiva, 2004; Basu, 2004).

As far as our study is concerned, there were several underlying questions deemed relevant: what will the grade of satisfaction of the students and of the internal collaborators be? What kind of diagnosis will the internal collaborators and managers of the Academic Services make? What are the weak and strong points of the Academic Services? Which improvement measures can be devised?

Our study aims at being the basis of a self-assessment tool to be systematically undertaken at the Academic Services of the University of Évora, a tool which will provide a means to develop a process of continuous progress, based on a systematic self-assessment. To meet this end, answers to the above questions will have to be given regularly.

\section{Quality: a general and brief overview}

The concept of quality comprises several dimensions, such as the ones dealing with assistance and technical/functional features of a product or service, the aesthetic appearance, cost, safety and the environment. Being some of these dimensions subjective, they are difficult to be measured accurately. Hence, quality must be objectified and quantified in such a way as to be measurable and, therefore, controlled (Pires, 2004).

There are, thus, several definitions of quality, one complementing the other and leading to the achievement of excellence. The definition of quality is dependent on the person who defines it and on his/her particular goals.

Given the subjectivity comprised in the definition of quality, it is now imperative to harmonize, identify and clarify the concepts underlying our research.

Quality is a term actualised in daily social or working interactions. Despite covering a wide range of meanings, the term is difficult to be defined due to its complexity and lack of consensus. According to António and Teixeira (2007) "the habitual definitions of quality emphasise one of the three perspectives of development of the product or service [..] Process - Results - Consequences" (our translation). Table 1 below, adapted from that same work, shows a synthesis of several definitions of quality, under the perspective of products or services development.

\begin{tabular}{|c|l|c|}
\hline Author & \multicolumn{1}{|c|}{ Definition of Quality } & Perspective \\
\hline $\begin{array}{c}\text { Shewart } \\
(1939)\end{array}$ & It is something subjective or objective & Process \\
\hline $\begin{array}{c}\text { Feigenbaum } \\
(1949)\end{array}$ & $\begin{array}{l}\text { It is a management form and must involve the } \\
\text { participation of everybody and aim at the } \\
\text { customers }\end{array}$ & Consequences \\
\hline Silva (1955) & $\begin{array}{l}\text { What characterizes a person or thing and } \\
\text { makes her/it to be different from another }\end{array}$ & Results \\
\hline $\begin{array}{c}\text { Crosby } \\
(1979)\end{array}$ & Conformity with the requisites & Results \\
\hline $\begin{array}{c}\text { Ishikawa } \\
(1985)\end{array}$ & $\begin{array}{l}\text { Lack of variation in the characteristics of } \\
\text { quality }\end{array}$ & \\
\hline
\end{tabular}




\begin{tabular}{|c|c|c|}
\hline $\begin{array}{l}\text { Shingo } \\
(1986)\end{array}$ & $\begin{array}{l}\text { Process of continuous monitoring and } \\
\text { instrument of potential feedback }\end{array}$ & Process \\
\hline $\begin{array}{c}\text { Taguchi } \\
(1986)\end{array}$ & $\begin{array}{l}\text { The loss that a product causes to society after } \\
\text { being shipped and not the losses caused by } \\
\text { intrinsic functions }\end{array}$ & Consequences \\
\hline Juran (1988) & Adaptation to use & Consequences \\
\hline $\begin{array}{l}\text { Peters } \\
(1989)\end{array}$ & $\begin{array}{l}\text { Never achieved but constantly searched for, } \\
\text { always aiming at the customer's needs }\end{array}$ & Results \\
\hline $\begin{array}{l}\text { Moller } \\
(1992) \\
\end{array}$ & $\begin{array}{l}\text { The quality of the product should not be the } \\
\text { focus; human resources should }\end{array}$ & Process \\
\hline $\begin{array}{l}\text { Deming } \\
(1992)\end{array}$ & $\begin{array}{l}\text { The process that leads to results through } \\
\text { products/services that may be sold to } \\
\text { costumers who will like them }\end{array}$ & Process \\
\hline $\begin{array}{l}\text { Tribus } \\
(1993)\end{array}$ & $\begin{array}{l}\text { What makes a customer love the product or } \\
\text { service }\end{array}$ & Consequences \\
\hline $\begin{array}{c}\text { ISO } 8402 \\
(1994)\end{array}$ & All the characteristics of an entity & Results \\
\hline $\begin{array}{l}\text { ISO } 9000 \\
(2000)\end{array}$ & $\begin{array}{l}\text { Level of satisfaction of requisites given by a set } \\
\text { of intrinsic features }\end{array}$ & Consequences \\
\hline $\begin{array}{c}\text { Associação } \\
\text { Portuguesa } \\
\text { para a } \\
\text { Qualidade } \\
\text { (APQ) }\end{array}$ & $\begin{array}{l}\text { All features of a product or service that } \\
\text { determine their aptitude to satisfy a certain } \\
\text { need }\end{array}$ & Results \\
\hline $\begin{array}{c}\text { American } \\
\text { Society for } \\
\text { Quality } \\
\text { Control } \\
\text { (ASQC) }\end{array}$ & $\begin{array}{l}\text { Quality is the sum of all the characteristics of a } \\
\text { product or service that bear on its ability to } \\
\text { satisfy certain needs }\end{array}$ & Results \\
\hline
\end{tabular}

Table 1. Synthesis of the definitions of quality

Quality is still an important issue. It is a factor of competitive advantage which enables the institutions to improve their performance in a rapidly changing world. As one of the dynamic factors of competitiveness, quality is, undoubtedly, a fundamental pillar of the success of the organizations.

Public institutions have deep responsibilities in society. Their ultimate goal is to meet their customers' needs, as it is the case of both Education and Healthcare, two essential social needs. Today, any organization aims at satisfying its customers.

\section{The Common Assessment Framework Model}

Public organisations have started to implement the principles of quality in a significant way (Gaster, 1996) since the 1990's of the last century.

To implement a process of change in an organization is a difficult task. Today, one of the great competitive advantages of an organization is the quality of its services. Yet, to be able to determine the quality of a service one must assess/measure that supposed advantage. Public services are no exception: they must be assessed in terms of quality, so that they provide a quality service to their customers. 
The CAF model is a Quality Management tool that has evolved along the years and that is being increasingly used across Europe. According to a study by the European Institute of Public Administration (EIPA) in 2003, CAF had been used by ca. 500 organizations, in 22 European countries. These data prove that the organizations began to adhere to the principles of quality in a significant way, namely after the 1990's (DGAP, 2005; Lopes and Capricho, 2007)

The Common Assessment Framework (CAF) is a self-assessment easy-to-use tool conceived for Public Organizations, with well-defined, useful practical results.

The CAF model is based on a structure comprising nine criteria to be considered in an organizational analysis, out of which 5 deal with the enablers (referring to what the organization does) and 4 with the results (referring to the results expected). Each criterion has several optional levels of assessment and is further broken down into some sub-criteria, which allows the identification of the main issues that must be considered in the assessment, as illustrated in Figure 1

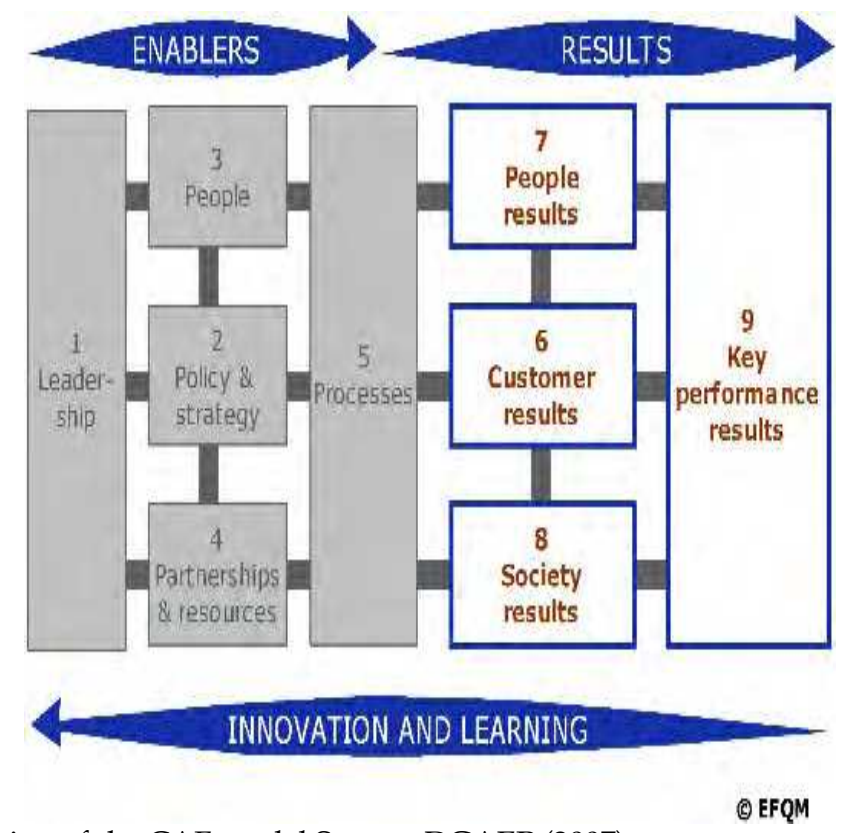

Fig. 1. Presentation of the CAF model Source: DGAEP (2007)

To undertake an accurate self-assessment by means of the CAF, one must take into consideration some phases of its planning, so that the value of the assessment may be optimized (DGAP, 2005), as Figure 2 shows. 


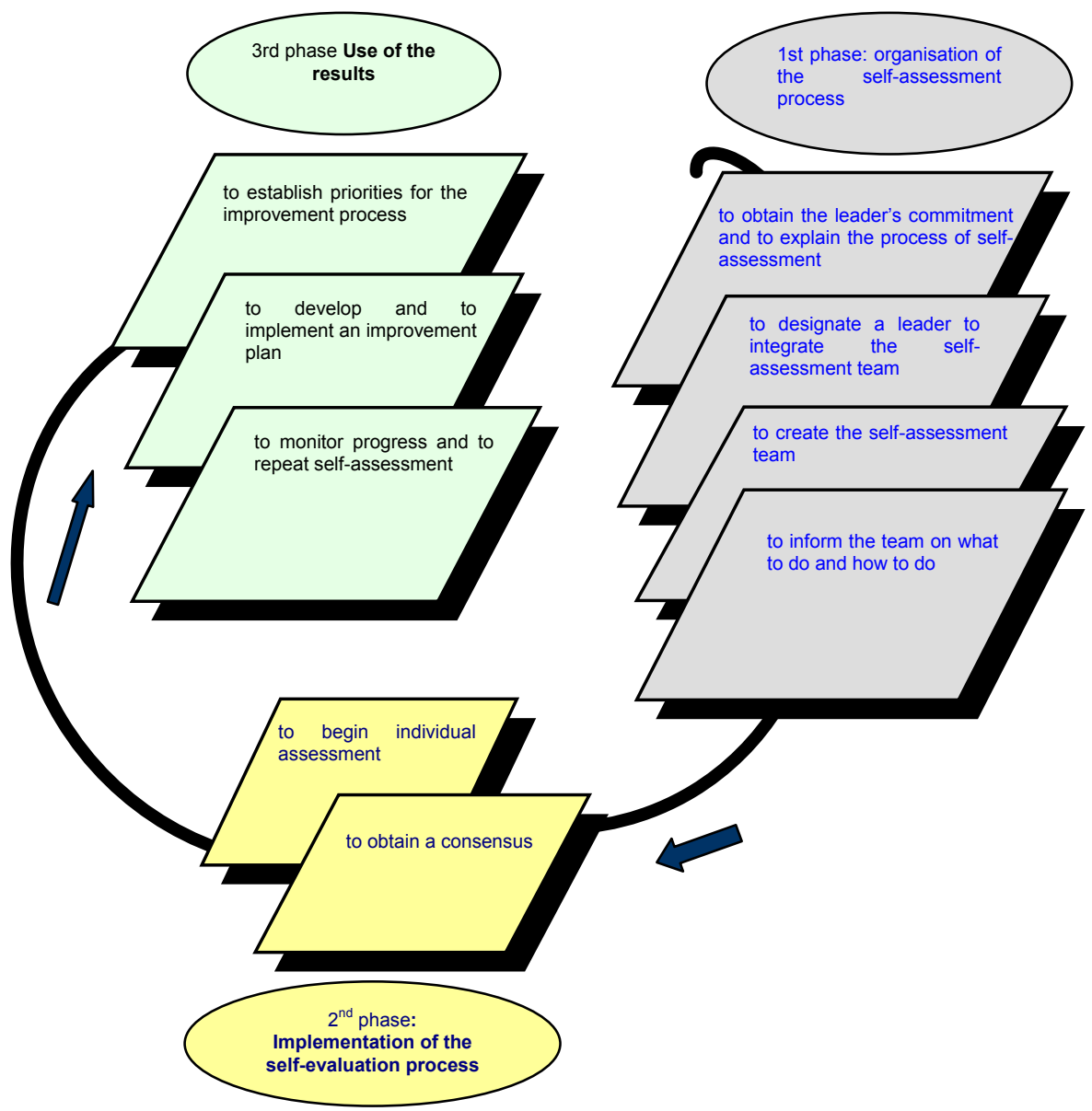

Fig. 2. Phases of application of the CAF model Source: Adapted from DGAP (2005)

First phase - Organisation of the self-assessment process - the steps to be followed are:

1) To obtain the leader's commitment and to explain the process of self-assessment the top managers must support the use of CAF and agree with all its underlying aspects; to define the mission of self-evaluation and the actions to be developed after the conclusion of the exercise;

2) To designate a leader to integrate the self-assessment team - the leader must provide the self-evaluation team with all the information and documentation needed; provide further contacts; hold meetings, etc;

3) To create the self-assessment team - the self-evaluation process involves the constitution of an ad-hoc team which should be representative of the organisation (different levels and sectors). This team, desirably small in number, will give an accurate and detailed internal perspective of the organisation. The top manager can also be the leader of the project; 
4) To inform the team about what to do and how to do it - the CAF model must be presented and the objectives and the nature of the procedures for self-evaluation must be explained. The guarantee of no retaliation upon the elements of the team must be ensured so that they can express their opinions freely.

Second phase - Implementation of the self-evaluation process - the stages to be adopted are:

1) To begin individual assessment - the team leader should be at the disposal of the other elements during the individual evaluation process. Each member should evaluate the organisation accurately, explaining the weak and strong points detected by means of the indicators and the punctuation given.

2) To obtain a consensus - the evaluation team should meet afterwards and agree on the punctuation to be given to the sub-criteria. The team leader has an important role in this process as the most important and relevant indicators for the organisation must be found.

Third phase - Use of the results - the phases are as follows:

1) To establish priorities for the improvement process - the organisation board of directors must be informed of the self-evaluation records so that the main results of the self-evaluation may be identified and analysed. To prepare the action plan, there are several questions to be considered: "Where do we want to be in the next 5 years?" (Objectives) and "What must we do to achieve these goals?" (Strategy/Plan of action). The Direction Board will be able to choose the areas to improve and set the priorities afterwards.

2) To devise and to implement an improvement plan - when CAF is used as a starting point for a long-term improvement process, evaluation can start by the identification of areas that require a simple and rapid intervention. The people that have done the self-evaluation must be included in this process.

3) To monitor progress and to repeat self-assessment - during the implementation of changes, it is important to know if the changes have produced the desired positive effect and if they are not damaging the activities that were executed properly.

Bearing in mind that quality management aims to provide the organization with the opportunity to learn more about itself and that the quality conceptual framework can be applied both in industrial organizations and in all parts of the public sector (Loffler, 2001; António and Teixeira, 2007), any public institution, when applying the CAF model, learns how to use a model of organizational analysis, how to practise self-assessment in a continuous and systematic way, how to develop a culture of public service aiming at leadership and to foster the strategic management based on the qualification and responsibility of people (Swiss, 1992; Morgan and Murgatroyd, 1994; Rago, 1994).

Considering these aspects, the Academic Services of the University of Évora became a suitable option given that it is a front-office service which serves a large community: students, teaching and non-teaching staff, managers and administrators, among others. It was, therefore, important to make it a pioneer in the process of continuous improvement at the University of Évora. 


\section{Methodology}

\section{Participants and procedures}

The Academic Services of the University of Évora, a front-office service, serve a vast community of customers composed namely by students, teaching and non-teaching staff, managers and administrators, fact that determined their being the first services in the university to be assessed.

When undertaking a process of self-evaluation it is of fundamental importance that the parties involved be heard. In this study and in the process of gathering information, structured questionnaires, in the form of opinion inquiries were thought to be very useful.

In 2006/2007 there were 5276 first-cycle students enrolled, and they constituted the basis for the representative sample. As for the collaborators ( 17 individuals) and managers (5 people), the questionnaires were applied to the totality of their population. Table 3 illustrates the populations, the location of application and the period of the study.

\begin{tabular}{|l|c|l|c|}
\hline \multicolumn{1}{|c|}{ Target Population } & Population & \multicolumn{1}{|c|}{$\begin{array}{c}\text { Location of } \\
\text { application }\end{array}$} & $\begin{array}{c}\text { Period of } \\
\text { study }\end{array}$ \\
\hline $\begin{array}{l}\text { First-cycle students of the } \\
\text { University of Évora enrolled in } \\
\text { 2006/2007 }\end{array}$ & 5276 & $\begin{array}{l}\text { Buildings of the } \\
\text { 'Campus' of the } \\
\text { University of Évora }\end{array}$ & $\begin{array}{c}\text { May and } \\
\text { June, 2007 }\end{array}$ \\
\hline $\begin{array}{l}\text { Managers of the Academic } \\
\text { Services of the University of } \\
\text { Évora }\end{array}$ & 5 & $\begin{array}{l}\text { Saint Augustine } \\
\text { Building } \\
\text { University of Évora }\end{array}$ & $\begin{array}{l}\text { October and } \\
\text { November, } \\
2007\end{array}$ \\
\hline $\begin{array}{l}\text { Non-teaching collaborators of } \\
\text { the Academic Services }\end{array}$ & 17 & $\begin{array}{l}\text { Saint Augustine } \\
\text { Building } \\
\text { University of Évora }\end{array}$ & $\begin{array}{l}\text { October and } \\
\text { November, } \\
2007\end{array}$ \\
\hline
\end{tabular}

Table 3. Target populations, location of application and period of study

The questionnaires were elaborated based on the models provided by the General Department of Public Administration and Employment (DGAEP)

There were 896 student valid respondents out of the 1000 questionnaires sent out, which means an $89,6 \%$ response rate. These questionnaires were applied in classrooms, and targeted the curricular units with the greatest number of students enrolled, not less than 20, in each degree offered at the university. 17 questionnaires were applied to internal collaborators of the services under analysis, corresponding to the totality of them. Out of these, there were 15 valid respondents, which represents an $88,24 \%$ response rate. All the managers were given a diagnosis questionnaire, and the response rate was $80 \%$. Collaborators and managers responded in their working locations what may have conditioned their answers to certain questions.

The respondent students were in their majority young, with an average age of 22 years, being $65,9 \%$ between $20-29$ years old. $93.3 \%$ of them were single, $63.6 \%$ were female and $89.5 \%$ were regular students.

The internal collaborators and managers of the Academic Services are in their majority young adults, with an average age of 35 years; $67 \%$ and $75 \%$, respectively, are married. Female collaborators and managers represent $78 \%$ and $100 \%$, respectively, and are 
academically qualified: $70 \%$ of the collaborators declared to have the $12^{\text {th }}$ grade and $30 \%$ declared to have a graduate degree; $100 \%$ of the managers have a graduate degree.

Variables

The variables considered in this study were the four criteria of enablers of the Common Assessment Framework (CAF), namely leadership, planning and strategy, people management and management of processes.

The Leadership criterion assists people in making a diagnosis and in assessing the way leaders develop actions and behaviours when implementing the management system of the organisation. The criterion of planning and strategy is useful to know how the organisation implements its mission, vision and values, thus allowing a diagnosis of whether the strategy is based on adequate policies, plans, objectives and processes. The criterion of people management is the support and the competitive advantage of the organisations, hence it is crucial to know how the organization manages, develops and transfers knowledge and the people potential, and assess their degree of satisfaction. With the criterion of management of processes and change one seeks to make a diagnosis and an evaluation of the processes, how the organisation conceives, manages and improves its processes. The analysis of these four criteria of the CAF model was made with the purpose of obtaining strong and weak points and improvement actions. This way the Academic Services will learn more about themselves and will improve quality.

The three questionnaires contained closed, mixed and / or overt questions and the four criteria of enablers of the CAF model were applied, namely leadership, planning and strategy, people management and management of processes and change management, as illustrated in Figure 3 below.

\section{Instruments}

To obtain the necessary information, three structured questionnaires as opinion enquiries were applied. A first questionnaire of satisfaction was applied to the students; a second questionnaire of satisfaction and diagnosis was applied to the internal collaborators and a third questionnaire of diagnosis was applied to the managers of Academic Services. These instruments were created based on the bibliographic revision and on the models available at DGAEP (DGAP, 2005; DGAEP, 2007).

\section{Data analysis}

The questions on the three questionnaires were closed, mixed and/or overt. For the overt questions the steps indicated by Lincoln and Guba (1985) were followed. Both the methodology suggested by Bardin (1984) and by Creswell (1984) and the associative analysis of Osgoog (in Vala, 1989) were also used. A posteriori categorization system was created with the purpose to obtain a simpler representation of raw data. It is a common belief that using this system the transcription of the reality does not change. The criterion used in the categorization was Semantic. Thematic categories were created and compounded by a key-word. The indicators allow the revelation and codification of the indexes associated to the registration units. For closed questions, data were treated with descript statistics techniques, by means of SPSS software (version 15.0).

To analyse the variables (4 criteria of enablers of CAF: leadership, planning and strategy, people management and management of processes), the generic model was adopted, as illustrated by Figure 3 below. 


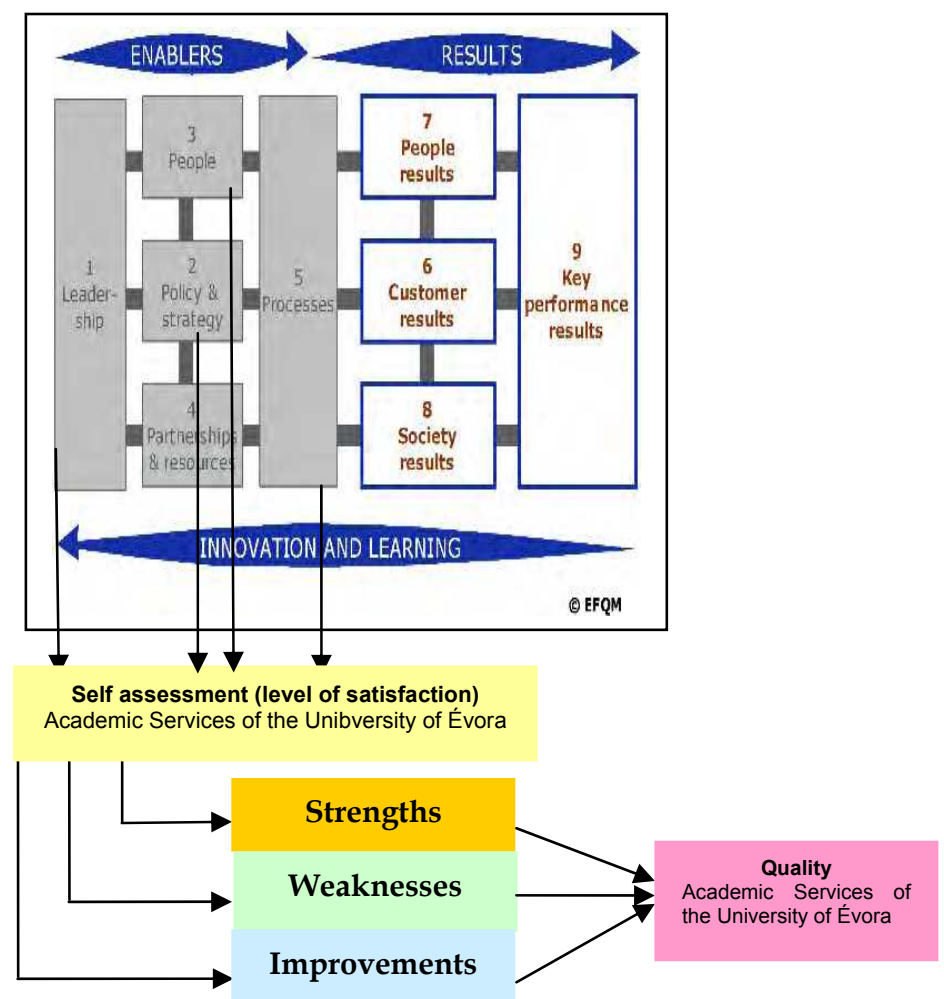

Fig. 3. Generic model

The analysis of the four criteria was found useful to obtain the strong, weak and improvement points that will lead the Academic Services of the University of Évora to know themselves better (self evaluation and grade of satisfaction) and to obtain the desired quality level.

\section{Results}

The results obtained indicated that the majority of first-cycle students of the University of Évora are young female adults, single and regular students. The majority of them are satisfied with both the performance and the global image of the Academic Services. Location, products and services delivered were in general also appreciated in a positive way. However, the students didn't have any opinion on some services delivered either because they didn't know about them or because they had never been in need of them.

As for the Academic Services staff, the results show that the majority of them is composed by married females, and the average age is 35 years old. This population is qualified and has been working in the Academic Services for several years, the majority of them since their admission and integration into the services. 
The majority of the managers used to work in other services of the university and have academic qualifications to perform the tasks assigned to them.

\subsection{Results obtained from the students}

The undergraduate students of the University of Évora were, in their majority, young, single and female. $89.5 \%$ of respondents were regular undergraduate students. The majority of them were satisfied with both the performance and the global image of the Academic Services. Nevertheless, the majority of them revealed indifference towards the item concerning the diligence of corrective measures.

Students in general were satisfied with the accessibilities and with the services provided by the Academic Services. Results also showed that some had no opinion about some of the services delivered, mostly because they had never felt the need to use them.

The weak points identified had to do with office hours and waiting times, mainly. However, the suggestions they presented covered the following needs: further information on their curricula transition to Bologna, rapid and efficient answers to the questions asked, a better personalised reception, more efficient means for the announcement of important information and deadlines, less 'ambiguous' application forms, more computer terminals, better accessibilities for handicapped people; different location in the city centre with parking places, decentralization of the services (e.g. an office at every building of the University), introduction of other forms of payment besides credit or debit cards and cheques, payment of fees at the academic services, availability of timetables prior to the enrolment period; better furniture in reception desks.

\subsection{Results obtained from the collaborators}

The majority of collaborators are female, married and with an average age of 35 years. They are academically qualified and have long worked in these services, in which most of them were directly integrated.

Results show that the communication processes and the involvement of interested parties in the definition of the vision, mission and values of the services must be improved. It is clear that there is the need to establish the values and conduct codes of the organization, to set out both the strategic and the operational goals (in a short term) and to implement the actions deriving from the transformation of its vision and mission.

The collaborators of the Academic Services stated that their director is a good leader, in spite of the fact that he does not promote them, does not support training actions necessary for the improvement of organisational performance and does not discuss their individual performance with them. Some stated that there is not leadership by example. These collaborators are not involved in the elaboration of the plan of activities nor in the strategic objectives adopted or to be adopted by the University or the services. There is not effective negotiation regarding the objectives and priorities of their sector. Regardless of this, though, they give their opinion as they consider it important.

Planning and strategy implementation in the Academic services is considered defective, as it does not involve all the staff. The practice of hosting and integrating the collaborators seems to be positive, although in need of improvement. There is a lot to do in the area of management and career development as well as in the area of professional training. It seems 
that collaborators do not wish to answer these questions by lack of interest, motivation or any other factor which when spoken out would be dismissed as a mere conjecture.

The involvement of people by developing open dialogue and empowerment may be considered a weak point in the Academic Services, as the autonomy granted seems to be insufficient; responsibilities are not delegated to collaborators and the involvement of people is observed only in the internal communication and consensus between collaborators and managers on the objectives to achieve by the department.

The collaborators think that the global image of the Academic Services is good, irrespective of two weak points which they consider must be urgently improved: telecommunications and the electronic sending of forms. They demand a more efficient modernisation, more technical means and more qualified human resources. Although globally not satisfied, they recognise that the social role played by the services needs to be improved. Management and the management system need to be improved urgently in the areas of rewards, implementation and application of the assessment system, including the definition of individual and shared objectives

They are globally satisfied with their working conditions. The only weak point stated is the inequality of opportunities regarding promotions. The level of satisfaction in this domain is not very high, which means that the Academic Services must focus their attention on developing the human resources management policies and on creating the opportunities for the development of new competences.

They are not motivated for lifelong learning, nor do they like change. They prefer teamwork. Motivation strategies must be devised so as to engage them in lifelong learning, a practice of crucial importance in any organization.

Equipment is satisfactory, but should be improved. Hygiene and safety conditions should also be intervened. The leadership styles of both the principal manager and of the intermediate ones are different, the collaborators revealing a higher level of satisfaction with the latter. This may be due to a closer relationship between collaborators and intermediate managers.

The suggestions presented reveal that quality must be based on the modernization of the services and on the allocation of more human resources.

\subsection{Results obtained from the managers}

All managers are female, the majority is married and their average age is 35 years. The manager board comprises academically qualified managers, with a professional experience superior to 10 years and working at the University of Évora, on average terms, for more than 16 years. The manager board is fully aware of the importance of the mission and vision of both the University and of the Academic Services.

The vision has its focus on the maximum attainable quality by means of modern acts of management and efficient work. The values defended by the Academic Services are not clear despite the perception that they must be focussed on experience and on quality. The strategic goals of this service are acknowledged by everyone, but they are not consensual. For the managers these goals can either be an improvement on the relationship with the community or a constant improvement of the services delivered to the students and to the teaching staff.

The mission and vision of the Academic Services are not clearly transformed into strategic and operational goals or into actions. 
The assessment made by the managers reveals that the management system has to undergo a thorough analysis, evaluation and implementation, as there is a lack of important, measurable mechanisms and systems of assessment and of management of the total quality. The leadership style of each manager motivates the collaborators. The managers do not take part in the process of change of their respective sectors. They do not take part in the process of change in the sectors they manage. Each one of them is responsible for the implementation of any initiative considered relevant for the motivation of the collaborators and for the incentives that promote creativity and people's performance.

The Academic Services make use of adequate mechanisms to develop, revise and upgrade planning and strategy. To implement planning and strategy, their managers take simultaneous measures in their respective sectors. Common to all of them is the definition of responsibilities. The Academic Services need more collaborators. There are mechanisms to recognise exceptional performances. Planning, management and human resources improvement go hand in hand with the planning and the strategy defined for each sector. The Academic Services, although in an incipient, not very explicit way, identify and develop the people's competences in articulation with the organisational objectives and goals, be they individual or collective.

Results show a certain involvement of people in the definition of plans and strategies for their sectors, assuming responsibility for them. Improvement measures for processes are not identified. The new procedures are evaluated, a criterion that constitutes a weak point of the Academic Services. As a culture of resistance to change is nonexistent, it must be used to implement change practices. Benchmarking is yet to be exploited. Modernization will not occur unless the sectors are provided with essential means, involving all parties in the process. The assessment of the modernisation process must be transparent, purposeful and measurable.

\subsection{Collaborators' opinions versus managers' opinions}

When data provided by the collaborators and the managers are crossed, one sees that there is still a long way to go in the way the organization leaders develop and proceed on with the necessary mission, vision and values that will sustain the success of the academic Services in the long run.

From the data collected in the abovementioned questionnaires the generic model underlying this study can be completed, as in Figure 4.

\section{Conclusions}

Quality exists and can be defined according to the interest shown by those who refer to it or by those who are willing to make use of it (Morgan and Murgatroyd, 1994). There are, in fact, tools to measure quality and the CAF model used in this research work is living proof. Quality, being a factor of competitiveness, must be assessed continuously as this is the only way to establish the difference between organisations that promote quality and excellence and those that do not do so (Swiss, 1992; Rago, 1994; Kaboolian, 1999; Scharitzer and Kornda, 2000; Loffler, 2001).

In general terms, the study undertaken reveals that the mission and vision of the University of Évora are acknowledged by all respondents; that the managers are receptive to change unlike the collaborators who tend to be a barrier to change. Moreover, it shows that there is 
a good leadership, regardless of the lack of a collective involvement in the negotiation of objectives, of the participation of collaborators in the planning or in the definition of the strategy of the services. Leaders do not delegate responsibilities and the participation of managers in the processes does not seem to be a priority. People are not motivated to take training actions.

Consequently, the Academic Services now have some indicators on how to improve their image, accessibilities and performance. This is the right way to proceed on, knowing exactly where to go and what to achieve: excellence in the services delivered.

Due to some constraints, namely the ones related to lack of time and shortage of Human Resources, only some questionnaires were applied, contrary to the recommendations of the General Department of Public Administration and Employment (DGAEP) Thus, it is our intention to further this study based on a more representative sample of respondents teaching and working at the University of Évora and at other Institutions of Higher Education. The comparison to be established will certainly highlight the use of good practices.

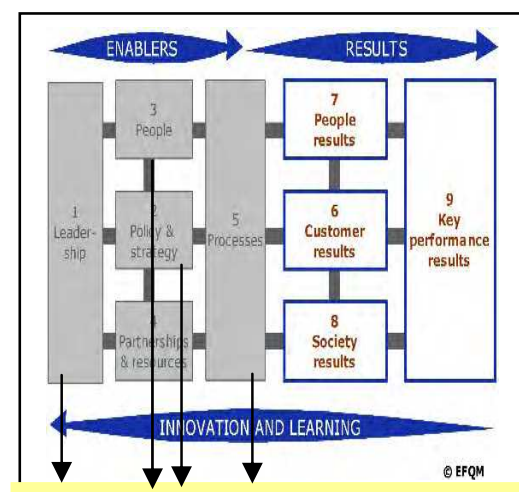

Self assessment (level of satisfaction)

Academic Services of the Unibversity of Évora

Strengths

- Good procedures in the integration of collaborators

- Articulation of the planning and strategy of sectors with the planning, management and improvement of human resources of the Academic Services

- Managers non- resistant to change

Weaknesses

- inadequate opening hours and long awaiting time

- collaborators are not given sufficient autonomy

- inadequate telecommunications system

- deficient sending of electronic forms

- inadequate facilities to address customers' needs

- customers spend too much time awaiting information

- services are not modernised

- technical means and human resources not enough

- inequalities regarding promotions

- collaborators are not motivated to engage in continuous training

- collaborators resist to change 


\section{Improvement}

- deep reform of means

- less bureocracy and simplication of processes

- more employees to addrees customers' needs

- More information on the Bolonha Declaration and its implications on curricula

- less time spent awaiting information

- better and ampler advertisement of important deadlines and other type of information

- academic timetables before the beginning of enrollment period

- Office hours extended to lunchtime and evening

Fig. 4. Self-Assessment model of the Academic Services of the University of Évora

\section{References}

António, N. S. e Teixeira, A. (2007). Gestão da qualidade - de Deming ao modelo de excelência da EFQM, Lisboa: Edições Sílabo.

Araújo, J. F. (2001). “Improving public service delivery: the crossroads between NPM and traditional bureaucracy." Public Administration. 79(4): 915-932.

Araújo, J. F. (2004). A Reforma da Gestão Pública: do mito à realidade. A Reforma da Administração Pública - apostas e casos de sucesso. Instituto de Gestão e Administração Pública (IGAP).

Associação Portuguesa para a Qualidade (APQ) (1995). Qualidade em movimento, Lisboa: APQ.

Bardin, L. (1994). Análise de conteúdo. Lisboa: Edições 70.

Basu, R. (2004). Implementing Quality: Practical guide to Tools and Techiques. London: Thomson Learning.

Creswell, Jonh (1994). Research Design: Quantitative and Qualitative Approaches. Thousand Oaks: SAGE Publications.

Crosby, P. B. (1979). Quality is free. The art of making quality certain, Nova York: McGraw-hill Book Company.

Dearing, Elisabeth; Staes, Patrick; Prorok, Thomas (2006). CAF works - better service for the citizens by using CAF. Publicações do EIPA.

DEMING, W. E. (1986). Quality, productivity and competitive position, MIT, Massachusetts: Center for Advanced Engineering Study.

Deming, W. E. (1992). Quality, productivity and competitive position, Cambridge: Massachusetts Institute of Technology.

Direcção Geral da Administração e Emprego Público (DGAEP), (2007), Estrutura Comum de Avaliação (CAF). Melhorar as organizações públicas através da auto-avaliação. Consultado em 16 de Junho de 2008. http://www.dgap.gov.pt/10 _CAF_2007/ 01_CAF2006/ModeloCAF2006_edicao_portuguesa_27abril.pdf

Direcção-Geral da Administração Pública (DGAP) (2005). Manual de apoio para aplicação da estrutura comum de avaliação (CAF), Lisboa: DGAP. 
Direcção-Geral da Administração Pública (DGAP) (2003) “Study for the Italian Presidency on the use of the Common Assessment Framework (CAF) in European Public Administrations". Rome. Consultado em 12 de Novembro de 2007. http://www. dgap.gov.pt/docs_down/caf_giq/download_docs_caf.htm.

Evans, J. R. e Lindsay, W. M. (2005). The management and Control of Quality. 6e. Singapore: Thomson South-Western.

Feigenbaum, A. V. (1949). Total quality control, Nova Iorque: McGraw-Hill.

Gaster, L. (1996). "Quality services in local government: a bottom-up approach". Journal of Management Development. 15(2): 80-96.

Gonçalves, I.; Monteiro, L. (1999). Serviços Públicos: da Burocracia à Qualidade. Lisboa: Secretariado para Modernização Administrativa.

Instituto Nacional de Administração (INA) (2006). Práticas da Aplicação da CAF na Administração Pública Portuguesa. Oeiras: Instituto Nacional de Administração.

Ishikawa, K. (1985). What is total quality control? The japanese way, Englewood, New Jersey: Prentice Hall.

ISO (1994). Norma NP EN ISO 8402, Quality vocabulary, Caparica: IPQ.

ISO (2000). Norma NP EN ISO 9000:2000, Sistemas de gestão da qualidade - requisitos, Caparica: IPQ.

Juran, J. M. (1964). Managerial breakthrough, Nova Iorque: McGraw-Hill

Juran, J. M. (1988). Quality control handbook, Nova Iorque: McGraw-Hill.

Kaboolian, L. (1999). "Quality Practices in the Public Sector". In Cole, R. and Scott, W. R. (eds.). The Quality Movement and Organization Theory. New York: Sage Publications. 132-153.

Lincoln, Y., y Guba, E. (1985). Naturalistic inquiry. Beverly Hills: California, Sage Publications.

Loffler, E. (2001). “Defining and Measuring Quality in Public Administration”. Teaching and Research Review, vol.5.

Lopes, A. e Capricho, L. (2007), Manual de gestão da qualidade, Lisboa: Editora RH, Lda.

Moller, C. (1992). O lado da Qualidade: Maximizando a Qualidade dos Produtos e Serviços através do Desenvolvimento das Pessoas, São Paulo: Ed. Livraria Pioneira.

Morgan, L; Murgatroyd, S. (1994). Total Quality Management in the Public Sector - An international perspective. UK: Open University Press.

Peters, T. (1989). Thriving on chaos, Londres: McMillan

Pires, A. R. (2004). Qualidade, sistemas de gestão da qualidade, $3^{a}$ edição, Lisboa: Edições Sílabo.

Rago, W. V. (1994). "Adapting Total quality Management (TQM) to Government: Another Point of View". Public Administration Review. 54: 61-64.

Rocha, J. A. O. (2006). Gestão da Qualidade: Aplicação aos serviços públicos. Lisboa: Escolar Editora.

Saraiva, M. (2004), Gestão da Qualidade Total - Uma Proposta de Implementação no Ensino Superior Português, Unpublished Doctoral thesis in Management, ISCTE Business School, Lisbon.

Scharitzer, D.; Korunda, C. (2000). "New Public Management: Evaluating the Success of Total Quality Management and Change Management Interventions in Public Services from the Employees' and Costumers' Perspectives". Total Quality Management. 11: 941-953. 
Shewhart, W. (1939). Statistical method from the viewpoint of quality control, New York: Dover.

Shingo, S. (1986). Zero quality control: source inspection and the poka-yoka system, Cambridge, MA: Productivity Press.

Silva, F- J. (1955). Dicionário da língua portuguesa, Porto: Livraria Simões Lopes.

Silva, J. O. (2000). "Qualidade, Cidadania e Modernização Administrativa". Revista Portuguesa de Administração e Políticas Públicas. I(1): 106-111.

Skelcher, C. (1992). "Improving the Quality of Local Public Services". The Service Industries Journal. 12(4): 463-477.

Swiss, J. E. (1992). “Adapting Total quality Management (TQM) to Government". Public Administration Review. 54: 356-362.

Taguchi, G. (1986). Introduction to quality engineering, New York: White Plains.

Tribus, M. (1993). 'Quality management in education', Journal for Quality \& Participation, Vol.16, n. ${ }^{\circ} 1$, Jan/Feb, 12-21

Vala, J. (1989). A análise de conteúdo. In A. S. Silva e J. M. Pinto (Orgs.). Metodologia das ciências sociais. 3. ${ }^{\mathrm{a}}$ ed. Porto: Edições Afrontamento. 


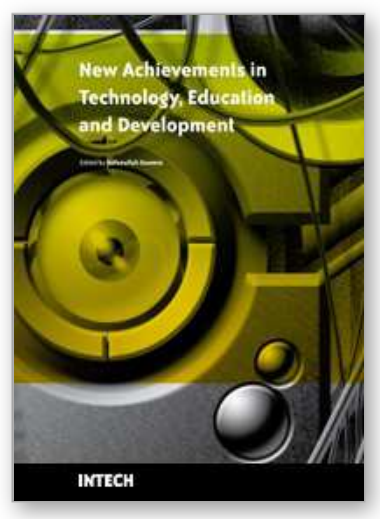

\author{
New Achievements in Technology Education and Development \\ Edited by Safeeullah Soomro
}

ISBN 978-953-307-066-7

Hard cover, 460 pages

Publisher InTech

Published online 01, March, 2010

Published in print edition March, 2010

Since many decades Education Science and Technology has an achieved tremendous recognition and has been applied to variety of disciplines, mainly Curriculum development, methodology to develop e-learning systems and education management. Many efforts have been taken to improve knowledge of students, researchers, educationists in the field of computer science and engineering. Still many problems to increase their knowledge on daily basis so this book provides newly innovations and ideas in the field of computer science and engineering to face the new challenges of current and future centuries. Basically this book open platform for creative discussion for future and current technologies to adapt new challenges in education sector at different levels which are essential to understand for the students, researchers, academic personals and industry related people to enhance their capabilities to capture new ideas and provides valuable contribution to an international community.

\title{
How to reference
}

In order to correctly reference this scholarly work, feel free to copy and paste the following:

T. Nogueiro and M. Saraiva (2010). The Use of the Common Assessment Framework Tool: Empiric Study on the University of Evora (Academic Services), New Achievements in Technology Education and Development, Safeeullah Soomro (Ed.), ISBN: 978-953-307-066-7, InTech, Available from:

http://www.intechopen.com/books/new-achievements-in-technology-education-and-development/the-use-ofthe-common-assessment-framework-tool-empiric-study-on-the-university-of-evora-academic-se

\section{INTECH}

open science | open minds

\section{InTech Europe}

University Campus STeP Ri

Slavka Krautzeka 83/A

51000 Rijeka, Croatia

Phone: +385 (51) 770447

Fax: +385 (51) 686166

www.intechopen.com

\section{InTech China}

Unit 405, Office Block, Hotel Equatorial Shanghai

No.65, Yan An Road (West), Shanghai, 200040, China

中国上海市延安西路65号上海国际贵都大饭店办公楼 405 单元

Phone: +86-21-62489820

Fax: $+86-21-62489821$ 
(C) 2010 The Author(s). Licensee IntechOpen. This chapter is distributed under the terms of the Creative Commons Attribution-NonCommercialShareAlike-3.0 License, which permits use, distribution and reproduction for non-commercial purposes, provided the original is properly cited and derivative works building on this content are distributed under the same license. 